Dark Ages, the Medieval period and the Renaissance when its use is attested not only by the surviving gilded objects, but also by descriptions in a number of technological treatises ranging from the 'Mappae Clavicula' in the ninth century (34) to the works of Benvenuto Cellini in the sixteenth century (35).

\section{Acknowledgements}

My thanks are due to numerous colleagues in the British Museum who kindly loaned objects in their care for technological examination. In particular I am grateful to Messrs. T. G. H. James and W. V. Davies, of the Department of Egyptian Antiquities, for references to the manufacture of gold foil and leaf in ancient Egypt.

\section{References}

1 Sir Edward Thomason, 'Memoirs During Half a Century', Vol. 1, London, 1845, pp. 65-66

2 I.. B. Hunt, Gold Bull., 1973, 6, (1), 16-27

3 I. G. Hawthorne and C. S. Smith, 'On Divers Arts: The Treatise of 'Theophilus', The Chicago University Press, Chicago, 1963, p. 112; reprinted Dover, New York, 1979

4 G. Williams, Chem. Br., 1978, 14, 567-569

5 British Museum, Department of Western Asiatic Antiquities. Part of inventoly No. 127430

6 O. M. Dalton, 'The Treasure of the Oxus with other Examples of Early Metal-Work', 3rd edition, Trustees of the British Museum, London, 1964, Cat. No. 4

7 R. J. Forbes, 'Studies in Ancient Technology', Vol. VIII, 2nd edition, E. J. Brill, Leiden, 197

8 British Museum, Department of Egyptian Antiquities. Papyrus No. 9940

9 T. G. H. James, 7. Egypt. Archaeol, 1965, 51, 51-52

10 C. M. Zivie, Bull. Inst. Fr. Archéol. Orient., 1975, 75, especially pp. 304-306

11 P. Duell et al., 'The Mastaba of Mereruka', Univ. Chicago Orient. Inst. Publ., Vol. 31 , Chicago, 1938, pl. 30 and 33
$12 \mathrm{~W}$. Wreszinski, 'Atlas zur Altägyptischen Kulturgeschichte', Vol. III, J. C. Hinrichs, Leipzig, 1936, pl, 34

13 Vatican Museum, Roman Sculpture No. 753

14 W. A. Oddy et al., in 'The Horses of San Marco, Venice', The British Academy, London, 1979, pp. 182-187

15 A. Burford, 'Craftsmen in Greek and Roman Society', Thames and Hudson, London, 1972

16 P. A. Lins and W. A. Oddy, 7. Archaeol Sci, 1975, 2, 365-373

17 D. de Coetlogan, 'An Universal History of Arts and Sciences etc.', London, 1745, see entry under 'gilding' on p. 1200

18 British Museum, Department of Egyptian Antiquities. Inventory No. 63593

19 British Muscum, Department of Greek and Roman Antiquities. Registration No. 1861, 4-25, 2

20 W. A. Oddy et al., in 'Proceedings of the 18th International Symposium on Archaeometry and Archaeological Prospection, Bonn, March 1978', Archaeo-Physika, 1979, 10, 230-242

21 British Museum, Department of Western Asiatic Antiquities. Inventory No. 134740

22 W. A. Oddy, PACT Education, in press

23 T. L. Shear, Hesperia, 1933, 2, 514-541, especially 519-527

$24 \mathrm{H}$. A. Thompson, in 'Athenian Studies presented to William Scott Ferguson', Harvard Studies in Classical Philology, Suppl. Vol. I, Cambridge, MA., 1940, p. 198 ff.

25 T. L. Shear, Hesperia, 1973, 42, 121-179, especially pp. 165-168

26 C. Hauser, in 'Greece and Italy in the Classical World', edited by J. N. Coldstream and M. A. R. Colledge, Acta of the 11 th International Congress of Classical Archaeology, London, 1978 , p. 222

27 H. Rackham, 'Pliny: Natural History', Vol. 9, Loeb Classical Library, London, 1952 (reprinted 1968), p. 175

28 H. Rackham, 'Pliny: Natural History', Vol. 9, Loeb Classical Library, London, 1952 (reprinted 1968)

29 W. A. Oddy and P. T. Craddock, unpublished results

30 S. Stucchi, Boll. Arte, 1960, 45, 7-44

31 At present in the care of the Department of the Environment (Ancient Monuments Laboratory) in London

32 P. T. Craddock, 7 . Archaeol. Sci., 1977, 4, 103-123

33 O. Vittori, Gold Bull., 1979, 12, (1), 35-39

34 C. S. Smith and I. G. Hawthorne, Trans. Am, Philos, Soc, $1974,64,1-128$

35 C. R. Ashbee, 'The Treatises of Benvenuto Cellini on Goldsmithing and Sculpture', Dover, New York, 1967

\title{
A First Century Model Ship
}

A fascinating little votive model of a lage sailing boat, found in 1891 at Broighter in County Derry in the north of Ireland and preserved in the National Museum of Ireland in Dublin, not only shows some early craftsmanship in gold but also establishes that shipbuilding by the Celts was well developed before the advent of the Romans. The model, about $20 \mathrm{~cm}$ in length, dates from the early first century A.D. and represents a ship of about $16 \mathrm{~m}$ in length. It is double ended, square rigged, and has thwarts for nine rowers on each side with a single steering oar on the port side. It was made

Photograph by courtesy of the National Muscum of Ireland, Dublin from one sheet of rather pale gold containing some silver, and represents either a wooden boat or one having a framework covered with hide.

L.B.H.

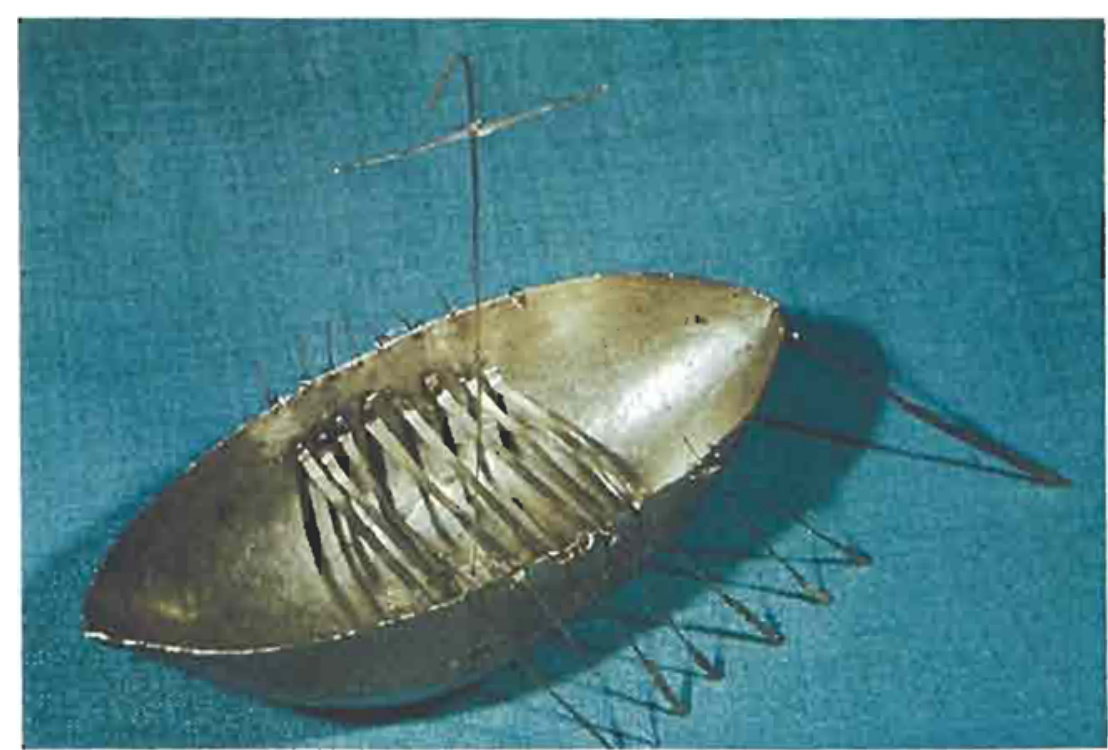

